\title{
Material for Strengthening of Entrance Edges of Work Blades of Stream Turbines
}

D. B. Glushkova, E. D. Grinchenko, L. L. Kostina, S. V. Demchenko, and Yu. V. Ryzhkov

Kharkiv National Automobile and Highway University,

25 Yaroslava Mudrogo Str.,

61002 Kharkiv, Ukraine

The influence of electrode material on the state of build-up layer of steam turbine rotor blades is investigated. The strengthening layer is formed by means of the electrospark alloying with use of alloy T15K6 and steel 15X11MФШ. Microstructure, microhardness, and thickness of build-up layer are investigated. The advantages of steel 15X11MФШ for the strengthening of leading edges of steam turbine rotor blades are substantiated.

Key words: electrospark alloying, electrode, surfacing layers, microstructure, microhardness, strengthening.

Досліджено вплив матеріялу електроди на стан натопленого шару робочих лопаток парових турбін. Зміцнений шар формувався електроіскровим легуванням стопом Т15К6 і крицею 15X11МФШ. Досліджувалися мікроструктура, мікротвердість і товщина натопленого шару. Обгрунтовано переваги криці 15Х11МФШ для зміцнення вхідних крайок робочих лопаток парових турбін.

Ключові слова: електроіскрове легування, електрода, натоплений шар, мікроструктура, мікротвердість, зміцнення.

Исследовано влияние материала электрода на состояние наплавленного слоя рабочих лопаток паровых турбин. Упрочнённый слой формировался электроискровым легированием сплавом Т15К6 и сталью $15 \mathrm{X} 11 \mathrm{MФШ.}$

Corresponding author: Diana Borysivna Glushkova

E-mail: diana@khadi.kharkov.ua

Please cite this article as: D. B. Glushkova, E. D. Grinchenko, L. L. Kostina,

S. V. Demchenko, and Yu. V. Ryzhkov, Material for Strengthening of Entrance Edges of Work Blades of Stream Turbines, Metallofiz. Noveishie Tekhnol., 39, No. 12: 16471654 (2017), DOI: 10.15407/mfint.39.12.1647. 
Исследовались микроструктура, микротвёрдость и толщина наплавленного слоя. Обоснованы преимущества стали 15X11МФШ для упрочнения входных кромок рабочих лопаток паровых турбин.

Ключевые слова: электроискровое легирование, электрод, наплавленный слой, микроструктура, микротвёрдость, упрочнение.

(Received September 7, 2017; in final version, November 24, 2017)

\section{INTRODUCTION}

Rotor blades of steam turbines determine the serviceability of the turbine. Their working conditions require high hardness of leading edges. Further, erosion damage reduces their resistance.

To increase the service life of blades, the leading edges are exposed to such processing methods like hardening by high-frequency currents and application of the widely used alloy T15K 6 based on carbides $\mathrm{Ti}$ and $\mathrm{W}$ as in forcing electrode. The binder for this alloy is Co.

However, the mode of operation of blades is such that requires increased resistance to shock erosion, lack of adverse influence of coating formation parameters on mechanical properties, high corrosion properties.

\section{ANALYSIS OF PUBLICATIONS}

Application of the above methods has limitations. Thus, using the high-frequency current makes it difficult to technically temper the radius blend from the blade air foil portion to the bookshelf bandage, and use of the widely applied alloy $\mathrm{T} 15 \mathrm{~K} 6$ as a reinforcing electrode is limited due to the presence of cobalt-an element that, as a result of activation, forms long-lived isotopes, which reduce the erosion resistance of blades [1,2].

In connection with the above, the objective of the present work was to develop a method that would enable to simultaneously reinforce the leading edges of blades and reduce their erosion resistance [3, 5].

\section{PURPOSE AND TASK}

In the given paper, there were tested two materials to be used as an electrode-alloy T5К16 and steel 15X11МФШ.

The electric spark method is based on the phenomenon of electric erosion of materials under spark discharge in a gaseous medium, the polar erosion product transport on the layer of modified structure and alloy. Because of electrical breakdown of the interelectrode gap, there occurs a spark, in which the flow of electrons leads to local heating of 
the electrode (anode) [1, 4]. On the surface of the cathode under the influence of high thermal loads, there is carried out a mixing of both the cathode and anode materials that promotes the formation of proper adhesion between the substrate and the formed layer. Figure 1 shows the general scheme of the electrospark alloying (ESA).

The composition of the doped layer may differ significantly from the composition of the raw materials. It is caused by the specifics of the ESA impact, which consists in the ultra-high heating and cooling rates, the contact of surfaces to each other and with the surrounding elements of the environment under pulse exposure to high temperatures and pressures.

The study was conducted, using samples of steel 15X11МФШ that was thermally treated to obtain the hardness of $285 \mathrm{HV}$ with removing the decarburized layer to the depth of $1 \mathrm{~mm}$ along the hardening plane.

Works on the strengthening of samples were carried out using electrospark equipment EIL 8A.

\section{PRIMARY PARTITION}

The microstructure of the base metal of specimens presents sorbitol with retaining orientation along martensitic planes. The structure of the samples is of different uniformity, the structure contains grains of different etch ability, and the size of needles corresponds to 7-8 points

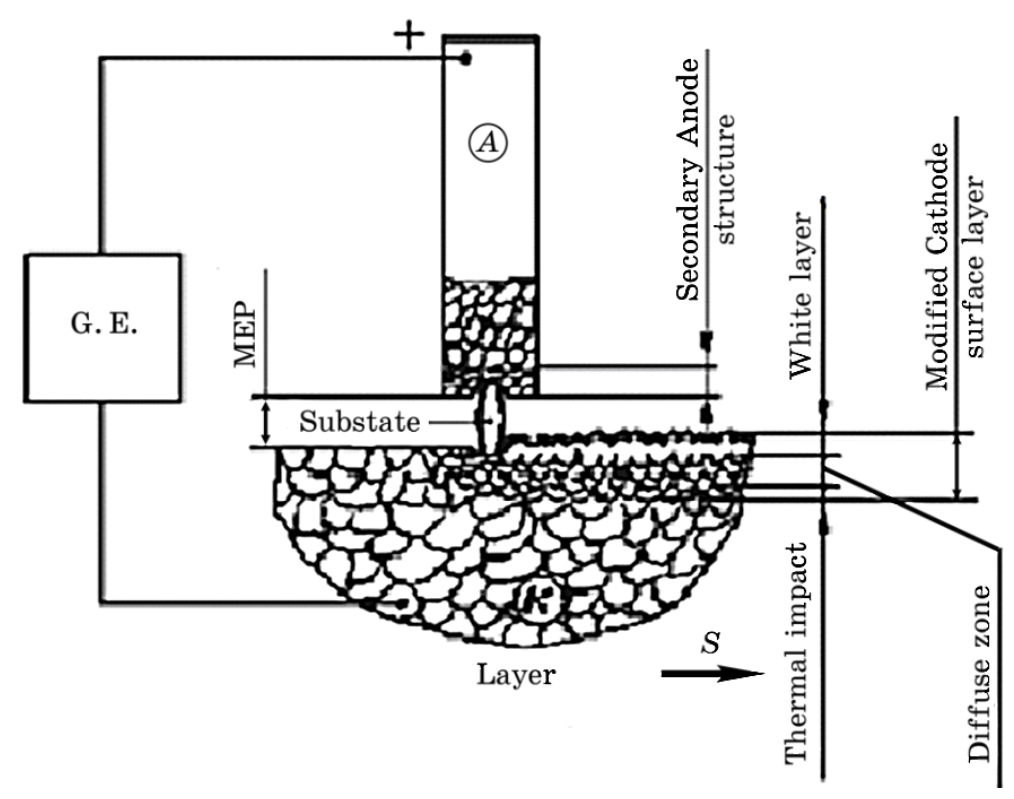

Fig. 1. General scheme of the electrospark alloying. 


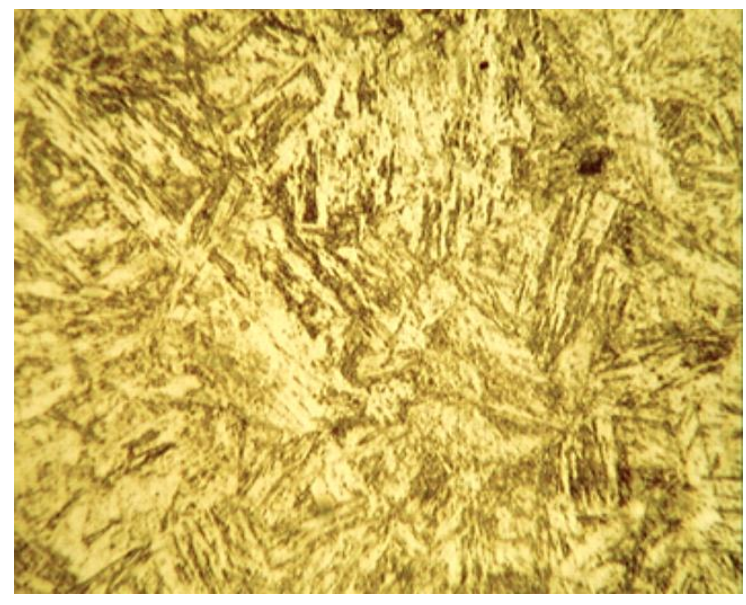

Fig. 2. Microstructure of the main sample metal.

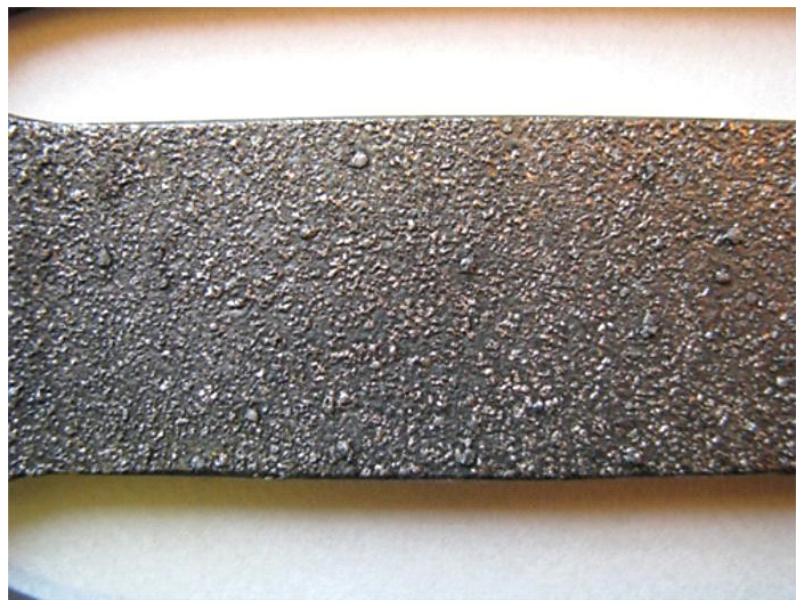

Fig. 3. The appearance of the sample surface strengthened by alloy T15K6.

(Fig. 2).

Control of the hardened surface is carried out by visual inspection with a magnifying glass with $\times 3, \times 10$ power.

On the surface of the samples after hardening by both alloys T15K6 and steel 15X11MФШ, defects such as cracks were not revealed. Figure 3 shows the appearance of the surface hardened by alloy T15K6. The layer is homogeneous, fine-grained, and, in some places, there can be found small size craters.

Figure 4 shows the appearance of the surface hardened by steel 15X11MФШ. The layer is homogeneous, fine-grained, and it has small 


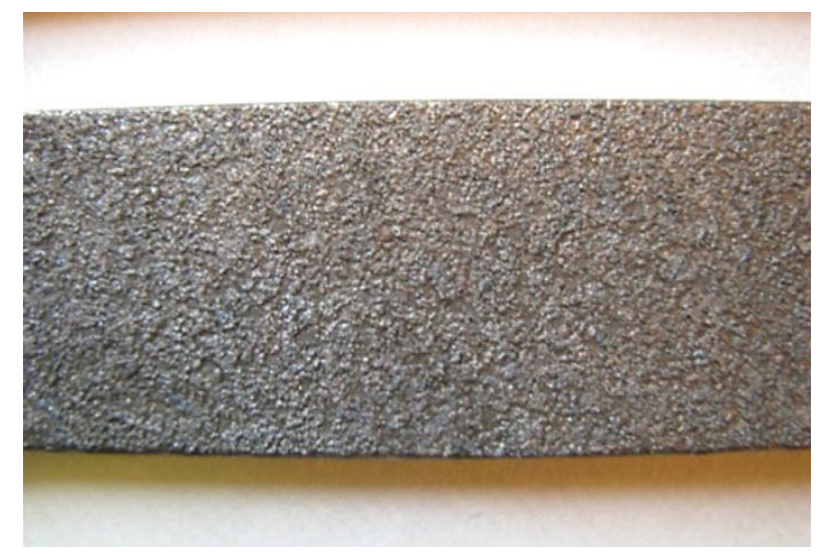

Fig. 4. The appearance of the sample surface hardened by steel 15X11MФШ.

TABLE 1. Bending test results.

\begin{tabular}{c|c|c|c}
\hline $\begin{array}{c}\text { Sample } \\
\text { brand }\end{array}$ & Material & Test result & Notes \\
\hline 1 & T15K6 & No ruination & In the place of bending, detected tears \\
2 & 15X11MФШ & No ruination & In the place of bending, detected tears \\
3 & 15X11MФШ & No ruination & In the place of bending, no detected tears \\
4 & 15X11MФШ & No ruination & In the place of bending, no detected tears \\
\hline
\end{tabular}

craters in small quantities.

To assess the quality of adhesion of doped layers with the substrate, the samples after hardening were tested according to the following scheme: samples Nos. 1 and 2 were tested for bending at an angle of $90^{\circ}$ using a mandrel with $R=20 \mathrm{~mm}$; samples Nos. 3 and 4 were tested for bending at an angle of $70^{\circ}$ using a mandrel with $R=40 \mathrm{~mm}$.

The test results are shown in Table 1.

When viewing the bends, the peel of the hardened layer from the base metal was not detected.

Measurement of the thickness of the hardened layer was carried out in sections manufactured according to the cross-sectional plane of the sample.

The surface hardened layer is characterized by heterogeneity of the layer thickness, but the average value of the thickness in case of hardening by alloy T15K6 and steel 15X11MФШ is virtually identical (Fig. 5).

Study of the microstructure of the deposited layer showed that the structure is homogeneous and almost no etch ability. In some places, there were detected individual pores. 


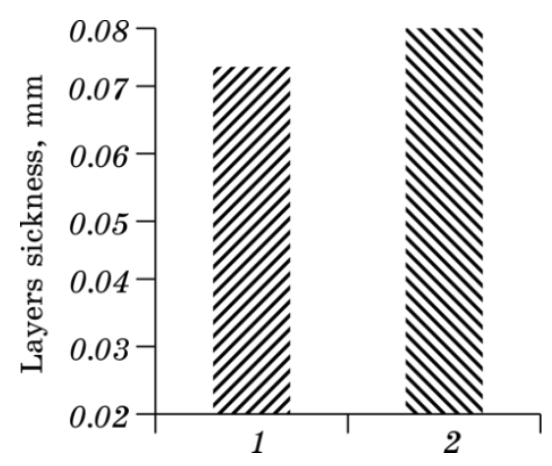

Fig. 5. Histograms of the mean values of thickness of layers hardened by alloy T15К6 (1) and steel 15X11MФШ (2).
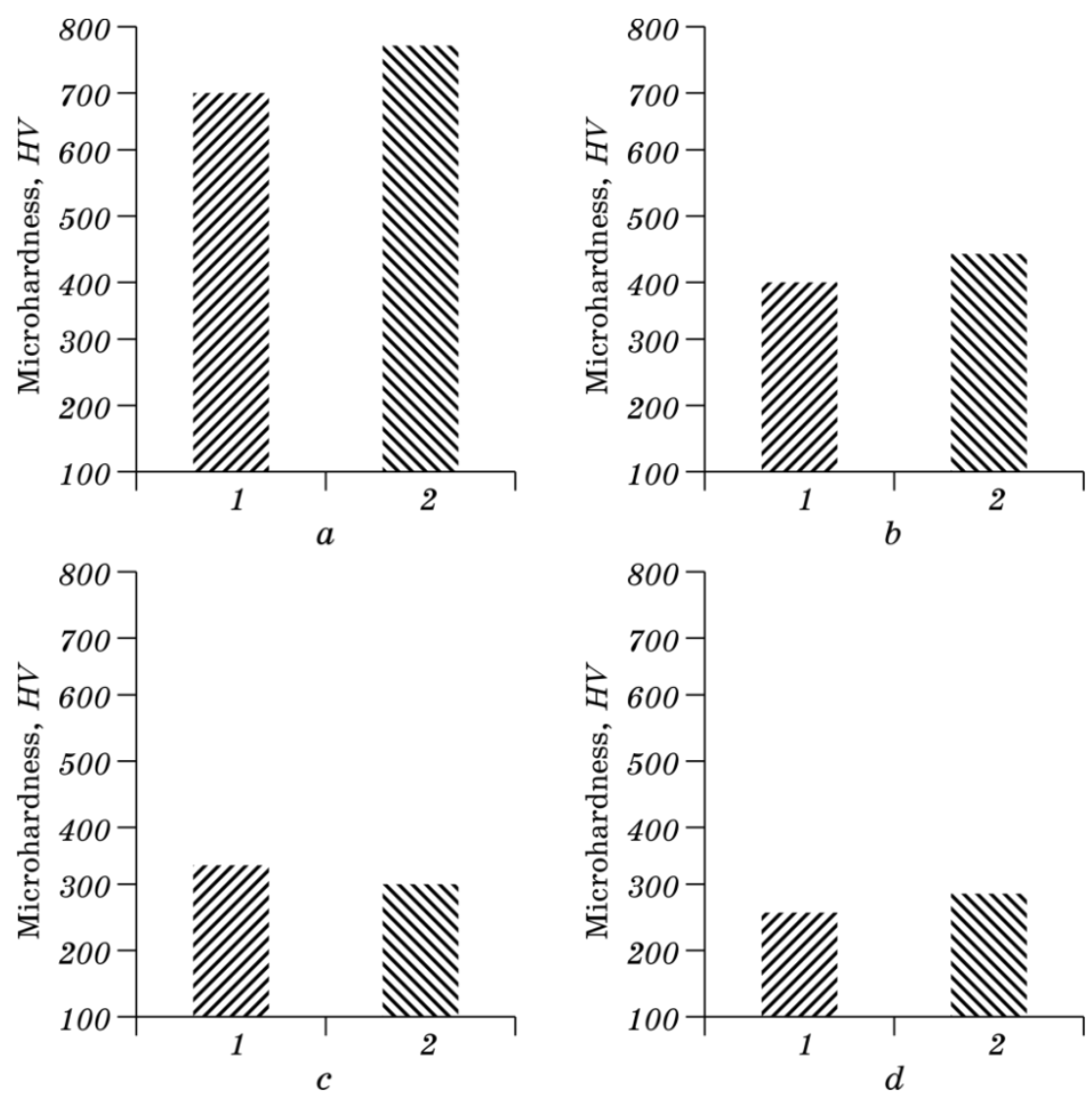

Fig. 6. Histograms of microhardness measurement in samples hardened by alloy T15K6 (1) and steel 15X11МФШ (2): $a$-deposited layer; $b$-transition (diffusion) zone; $c-\mathrm{HAZ}(\cong 0.05 \mathrm{~mm}$ from the border); $d-\mathrm{HAZ}(\cong 0.1 \mathrm{~mm}$ from the border). 
When surfacing by steel 15X11MФШ, the layer structure is of mainly dendritic structure. In the surface layer of the base metal under high temperatures, there was observed the formation of the light etch ability zone formed by diffusion of the electrode material into the sample depth and the dark-etch ability zone of under alloying. In some places, there were detected pores.

Figure 6 shows histograms of microhardness measurement in the zone 'hardened layer-base metal' of the samples under study.

As it follows from the above histograms, in all areas, the microhardness at hardening by alloy T15K6 and steel 15X11MФШ is practically identical.

\section{CONCLUSIONS}

1. When there was performed visual inspection and carried out metallographic analysis of samples reinforced by the electrospark method using the equipment EIL 8A with electrodes made of steel 15X11MФШ and hard alloy T15K6, cracks were not revealed.

2 . The bending tests of the samples hardened by both the solid alloy T15K6 and steel 15X11MФШ are not failed.

3. In examination of the bends, the peel of the hardened layer from the base metal was not detected.

4. The average thickness of the surface layer hardened by both alloy T15K6 and steel 15X11MФШ was virtually identical.

5 . The microhardness of the deposited layer, the transition zone, and HAZ at different distances from the boundary, when using both the hardened alloy T15K 6 and steel 15X11MФШ, is not practically different.

6 . Based on these studies, it is recommended to replace the applied reinforcing electrode with one made of alloy T15K6 and steel 15X11MФШ to increase the hardness of the leading edges of steam engine rotor blades.

\section{REFERENCES}

1. Yu. I. Mulin and A. D. Verkhoturov, Elektroiskrovoe Legirovanie Rabochikh Poverkhnostey Instrumentov i Detaley Mashin Elektrodnymi Materialami, Poluchennymi iz Mineral'nogo Syr'ya [Electrospark Alloying of Tools Surfaces and Machine Components with Electrode Materials Obtained from Mineral Raw Materials] (Vladivostok: Dal'nauka: 1999) (in Russian).

2. Sovremennye Metody Uprochneniya Poverkhnostey Detaley Mashin [Modern Methods of Hardening of Surfaces of Machine Parts] (Ed. K. W. Frolov) (Moscow: Institute Eng. Sci., Acad. Sci. USSR: 2009), Iss. 9.1: 205 (in Russian).

3. B. I. Kostetskiy, Trenie, Smazka i Iznos v Mashinakh [Friction, Lubrication 
and Wear in Machines] (Kiev: Tekhnika: 2000) (in Russian).

4. V. I. Bolshakov, V. I. Kharchenko, and V. N. Zhuravel, Perspectivnye Zadachi Sovremennoy Nauki: Sb. Nauchnykh Tr. (Dnepropetrovsk: 2002), p. 109 (in Russian).

5. V. I. Bolshakov, V. M. Volchuk, and Yu. V. Dubrov, Visnyk NAN Ukrayiny, No. 8: 66 (2013) (in Ukrainian). 